\title{
Innovation in the Public Sector in the Digital Era (A Study of the Process Diffusion of SIMPUS in Yogyakarta)
}

\author{
$1^{\text {st }}$ Deby Febriyan Eprilianto \\ Department of Public Administration, \\ Faculty of Social Sciences and Law \\ Universitas Negeri Surabaya \\ Surabaya, Indonesia \\ debyeprilianto@unesa.ac.id
}

\author{
$2^{\text {st }}$ Fitrotun Niswah \\ Departmen of Public Administration \\ Faculty of Social Sciences and Law \\ Universitas Negeri Surabaya \\ Surabaya, Indonesia \\ fitrotunniswah@unesa.ac.id
}

\author{
$3^{\text {rd }}$ Meirinawati \\ Department of Public Administration \\ Faculty of Social Sciences and Law \\ Universitas Negeri Surabaya \\ Surabaya, Indonesia \\ meirinawati@unesa.ac.id
}

\begin{abstract}
In Indonesia, innovation is associated with the utilization of Information and Communication Technology (ICT) in the process of public administration. The most important thing in doing an innovation is the process of innovation diffusion. The purpose of this research was to know and describe the process of diffusion of innovation, strategy and success factor in the process of diffusion of SIMPUS innovation in Yogyakarta City. This research was conducted at the Government of Yogyakarta City with a unit of analysis of the Health Department and all health centers. The results of this research indicate that the form of innovation of SIMPUS application is the innovation of technology-based administration process in health service made by Section Surveillant and SIK Yogyakarta City Health Office. The goal for data integration throughout health center implemented gradually from 2011 to 2013 at all health centers that is 18 central health centers and 12 auxiliary health centers. The process of diffusion of SIMPUS innovation does not occur incidentally but can be traced through the stages of the diffusion process that occurs, where at each stage are done various strategies both formal and informal. The study recommends innovators in the public sector to learn from the diffusion process frameworks, strategies and factors that influence the success of the innovation diffusion process.
\end{abstract}

Keywords- Innovation in the public sector, innovation diffusion process

\section{INTRODUCTION}

Generally, innovation is done by the private sector in providing services to its customers [1]. The success of the private sector in conducting various innovations began to be ogled by the public sector. Innovation in the public sector becomes an important discourse in various countries, especially in developed countries since the existence of it is considered to contribute in improving the quality of public services and can be a solution in solving public problems [2]. Innovation in the public sector is synonymous with changes or reforms by governments better known as the concept of new public management (NPM) [3], and the concept of e-government [4].

The importance of innovation in the public sector becomes an interesting study in developed countries, given that competition and the development of social change are increasingly complex where competition among service providers is increasing and influencing one another [2]. Innovation in the public sector is triggered by a process of communication or information dissemination of an innovation. The process of disseminating innovation requires a channel of communication and time to accept an innovation [5]. Innovation in the public sector is evolving to match existing needs and conditions, so long process stages are required and a proper selective attitude is needed to adopt an innovation.

In Indonesia, the understanding of innovation in the public sector can be seen from the various applications of innovation conducted in all lines of government [6]. Almost all government agencies understand innovation as the adoption of ICT use into the public administration process [7]. The relevance of innovation with e-government can be seen in the application of ICT to the environment of government agencies in providing electronic services publicly. Nevertheless, there are some institutions that understand innovation, not only about the use of ICT alone. The most important thing in innovation is the process of diffusion of innovation or dissemination. The sooner or later an acceptable innovation depends on the ability of an innovation to be known to others [8]. Application of an innovation is expected to improve the conditions and needs of others to be better than the previous conditions. In addition, an innovation that will be adopted by society must be absolutely able to be disseminated to the wider community in various ways [9].

The implementation of e-government in Indonesia began in 2003 along with the release of INPRES no. 3/2003 on National Policy and Strategy for Development EGovernment, but the conditions of its application vary. Since the implementation of e-government, all existing agencies have made innovations that are influenced by the rapid and widespread development of ICT [10]. The utilization of ICT in the public sector can be seen in various fields, such as etourism, e-education, e-health and so forth. The use of ICT in public administration is expected to provide public services that are fast, easy, precise, and cheap, so it can give 
more benefits compared with the use of manual or traditional way. Nowadays, public sector innovation in the digital era is growing rapidly in various fields such as eplanning, e-budgeting, e-project, e-procurement, e-delivery, e-controlling, e-service, e-performance, and so forth, but the increase only occurs in quantity only, while the quality is not on the same spotlight [6].

The development of facilities in the health sector has done well in developing and developed countries. As in China since 2005 has developed e-health but in the context of the system is still difficult [11]. Likewise in Australia, ehealth applications have been developed since 2000 and successfully released on July 1, 2012, the same in practice also contains a variety of challenges with criticism of the application [12]. The implementation of e-health in Bangladesh also has some challenges, especially on technical and managerial issues [13]. While in Indonesia ehealth development has been done on multi sectors with various applications.

SIMPUS is one of the pilot projects innovation in the Government of Yogyakarta City as a commitment to improve health services. The emergence of SIMPUS at every health center in Yogyakarta City has an episode and its implementation strategy, so it can be implemented optimally. The stages in the process innovation of SIMPUS happen through a long process. Therefore, SIMPUS became one of the best practices of innovation development in the public sector in the digital era in Yogyakarta City. The success makes the Government of Yogyakarta City served as a laboratory of regional innovation by the State Administration Institution in 2015. The development of SIMPUS applications in the Yogyakarta City can be seen in the table below.

TABLE I.

SIMPUS Application Development

\begin{tabular}{|c|c|l|}
\hline Phase & Year of & \multicolumn{1}{|c|}{ Service Activity } \\
\hline $\begin{array}{c}\text { Manual - } \\
\text { Traditional }\end{array}$ & Prior to 2005 & $\begin{array}{l}\text { All healthcare activities were } \\
\text { performed manually }\end{array}$ \\
\hline Transitions & $2005-2011$ & $\begin{array}{l}\text { Healthcare services, patients } \\
\text { registration system, pharmaceutical, } \\
\text { and payment were done manually } \\
\text { based on windows and medical } \\
\text { record system of patients using the } \\
\text { MedCis application }\end{array}$ \\
\hline SIMPUS & $2012-$ present & $\begin{array}{l}\text { All health service activities were } \\
\text { conducted using SIMPUS } \\
\text { application }\end{array}$ \\
\hline
\end{tabular}

Source: SIMPUS Implementation Guideline in Yogyakarta City, 2014

From the above table, it can be seen that SIMPUS development aims to process patients' medical record data aimed at all health centers in Yogyakarta. The most important thing in the development of SIMPUS is the realization of data integration system at all health centers where before SIMPUS application, every health center recorded the patients' data traditionally manual, although there were some health centers that had used the ICT, the method was still traditionally manual. With the existing development, the Health Office seeks to develop applications that can accommodate these needs. As a result, SIMPUS that was implemented in all health centers in Yogyakarta City that include 18 central health centers and
12 auxiliary health centers were created. Therefore, the researcher is interested to discuss more deeply about the diffusion process, strategy and factors influencing the diffusion process of SIMPUS innovation in Yogyakarta City.

\section{RESEARCH METHODS}

\section{A. Design}

This research used descriptive qualitative research design with a case study approach. This research tried to describe the existing phenomenon or event about innovation diffusion process in the public sector based on ICT on SIMPUS innovation in Yogyakarta City. This research was conducted at the Government of Yogyakarta City at Jalan Kenari 56 Yogyakarta 55156 that is in some work units of regional apparatus or SKPD, among others in Information Technology and Telematics (TIT), Health Department, and 18 central health centers and 12 auxiliary health centers. All health centers in Yogyakarta can be seen in the table below.

TABLE II.

Health Centers in the Yogyakarta City

\begin{tabular}{|ll|cl|}
\hline \multicolumn{5}{|c|}{ Central Health Center (CHC) } & \multicolumn{3}{|c|}{ Auxiliary Health Center (AHC) } \\
\hline 1. & CHC Tegalrejo & 1. & AHC Badran \\
2. & CHC Danurejan I & 2. & AHS Bener \\
3. & CHC Danurejan II & 3. & AHS Demangan \\
4. & CHC Gedongtengen & 4. & AHS Dukuh \\
5. & CHC Gondokusuman I & 5. & AHS Joyonegaran \\
6. & CHC Gondokusuman II & 6. & AHS Kepatihan \\
7. & CHC Gondomanan & 7. & AHS Mendungan \\
8. & CHC Jetis & 8. & AHS Nitikan \\
9. & CHC Kotagede I & 9. & AHS Pakel \\
10. & CHC Kotagede II & 10. & AHS Pathuk \\
11. & CHC Kraton & 11. & AHS Tegalmulyo \\
12. & CHC Mantrijeron & 12. & AHS Tompeyan \\
13. & CHC Mergangsan & & \\
14. & CHC Ngampilan & & \\
15. & CHC Pakualaman & & \\
16. & CHC Umbulharjo I & & \\
17. & CHC umbulharjo II & & \\
18. & CHC Wirobrajan & \multicolumn{4}{|c|}{ Source: Health Department of Yogyakarta, 2016 } \\
\hline
\end{tabular}

\section{B. Source and Data Collection Techniques}

This research used primary and secondary data sources. The primary data in this research was obtained from direct interview and observation of the research subject. The forms of secondary data in this research included laws and/or regulations, reports, notes, meeting minutes, report books, documentation, IKM, data and other relevant information. The secondary data was needed to complement and support the primary data related to the research problem. This research used 3 data collecting techniques, they are depth interview (in-depth interview) by using an interview guide, direct observation, and documentation.

\section{Analysis and Testing Data Validity}

The analysis in qualitative research begins by preparing and organizing data for analysis and then reducing the data into themes through the process of coding (categories of text or visual data into a smaller category) [14], then summarized $\mathrm{n}$ is conducted and last presents data in the form of charts, tables or discussions. The analytical technique used is an interactive analysis described by Miles and Huberman that is the analysis process performed simultaneously with the data 
collection process [15]. This data analysis process uses four stages, namely the stage of data collection, data reduction, data presentation, and withdrawal of conclusions. In qualitative research, valid data can be obtained by conducting a credibility test (validity as interval) [15]. The various tests of data credibility are triangulation technique, an extension of observation, use of the reference materials and negative case analysis and perseverance enhancement. This research will be testing the validity of data by using the triangulation technique.

\section{RESULTS AND DISCUSSION}

\section{A. SIMPUS as Innovation in the Public Sector}

Innovation according to Rogers is an idea, practice or object that is realized and accepted as something new by a person or group to be adopted [1] [16]. From the definition, it is difficult to distinguish between innovation and change. Osborne and Brown propose that innovation is a specific form of change, where innovation is a dotted change [17]. Meanwhile, according to Bloch, innovation consists of new and significant changes to services and goods, operational processes, organizational methods, or the way organizations communicate with users [18].

In general, innovation in the public sector aims to improve efficiency, increase transparency, improve service quality and increase user satisfaction. When referring to the definition, it is very clear that SIMPUS is an innovation made by the Health Department through the Surveillance section and Health Information System of Yogyakarta City in 2011. Previously, in 2005 the Health Department has a similar application that was developed by MedCis TIT of Yogyakarta City Regional Secretariat. Therefore, over time, MedCis applications cannot accommodate the needs of the Health Department. This was due to the incompatibility of applications with the needs of the Health Office. Hence, in 2011, the Health Department internally developed the SIMPUS application. The development of SIMPUS innovation development can be seen in the figure below.

Fig. 1.

Time Series in SIMPUS Innovation

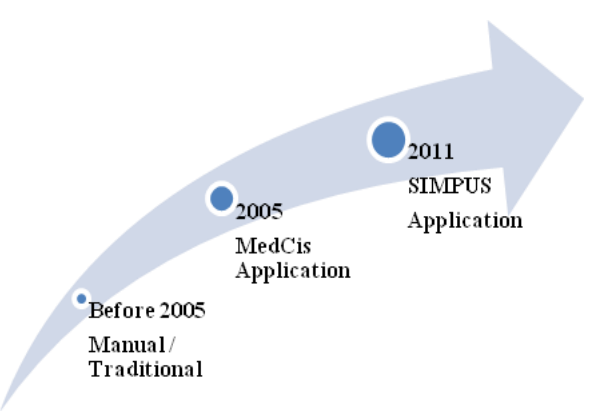

Source: Health Department of Yogyakarta, 2014

The innovative public sector can significantly improve service quality through new services, new aspects, ease of use, access, timeliness, and so on. The types of innovation in the public sector by Moore and Hartley include process innovation, product or service innovation, government innovation, and conceptual innovation [17]. This type of innovation can be seen in the table below.

TABLE III.

Types of Innovation in the Public Sector

\begin{tabular}{|c|c|c|}
\hline No & $\begin{array}{c}\text { Types of } \\
\text { Innovation }\end{array}$ & Remarks \\
\hline \multirow[t]{3}{*}{1.} & $\begin{array}{l}\text { Innovation } \\
\text { Process }\end{array}$ & $\begin{array}{l}\text { Improved quality and efficiency in internal } \\
\text { and external }\end{array}$ \\
\hline & $\begin{array}{l}\text { processes } \\
\text { Administrative } \\
\text { innovation } \\
\text { process }\end{array}$ & $\begin{array}{l}\text { Creation of new organizational forms, the } \\
\text { introduction of new methods, new } \\
\text { management and new techniques and new } \\
\text { jobs }\end{array}$ \\
\hline & $\begin{array}{l}\text { The process of } \\
\text { technological } \\
\text { innovation }\end{array}$ & $\begin{array}{l}\text { Creation or use of new technology, } \\
\text { introduced in an organization to provide } \\
\text { services to users and society. }\end{array}$ \\
\hline 2. & $\begin{array}{l}\text { The innovation } \\
\text { of products or } \\
\text { services }\end{array}$ & Creation of new products or public services \\
\hline 3. & $\begin{array}{l}\text { Governance } \\
\text { innovation }\end{array}$ & $\begin{array}{l}\text { Development of new forms and processes } \\
\text { for identifying social problems }\end{array}$ \\
\hline 4. & $\begin{array}{l}\text { Conceptual } \\
\text { innovation }\end{array}$ & $\begin{array}{l}\text { Introduction of new concepts, terms of } \\
\text { reference or new paradigms that help to } \\
\text { design new issues and solutions Appropriate }\end{array}$ \\
\hline
\end{tabular}

Referring to the type of innovation proposed by Moore and Hartley above, it can be concluded that SIMPUS innovation is included in the kind of process innovation both the innovation process of administration and the process of technological innovation. Based on the field data, it shows that SIMPUS innovation was developed in the form of applications by using ICT. SIMPUS innovation has the primary function of integrating all data and health information of every patient starting from patient registration, examination or record of patient data, treatment, and payment or billing at every health center. Meanwhile, the goal of SIMPUS innovation development is to improve the quality of health center management through optimum utilization of ICT to support the preparation of health information reporting. The strategy used in the SIMPUS innovation process in Yogyakarta City Health Office is topdown. This means that in the implementation of this program, the policies taken are binding and they become a necessity for the target group. In this case, every health center in Yogyakarta City has the obligation and it is a must to implement it. The Health Department is in full control of the diffusion process of SIMPUS innovation throughout the existing health centers where the diffusion process of SIMPUS innovation has a long episode until all health centers can apply it.

\section{B. The Process of Innovation Diffusion SIMPUS}

Rogers defines the diffusion of innovation as the process by which an innovation is communicated through a certain channel within a certain time period among members of a social system [8] [16]. In addition, diffusion can also be regarded as a kind of social change that is a process of change that occurs in the structure and social system. Therefore, diffusion is closely related to innovation, because the main purpose of the diffusion process is the adoption of a form of innovation by members of a particular social system that can be either individuals or groups. According to Rogers, there are four main elements inherent in the innovation diffusion process: (1) innovation, (2) 
communication channels, (3) time, and (4) social system [16]. Rogers also explains that the fundamental elements of the innovation diffusion process are that innovation is communicated through certain communication channels, within a certain timeframe, and occurs among members of the social system [9].

When referring to the element-related explanations of the innovation diffusion process above, it can be described more deeply related to the elements of the diffusion process of SIMPUS innovation. There are four elements attached to the process of diffusion of SIMPUS innovation. Those four elements are:

1) Innovation, in this case, Rogers explains that innovation is an idea, action or goods that are considered new by someone. Innovation novelty is measured subjectively according to the view of the individual who receives it. SIMPUS innovation is the result of MedCis application development. Its development is done internally by Surveillance and SIK Section of Health Department of Yogyakarta City, so it can adjust to their needs. This is because the Health Department is a party that understands the needs. SIMPUS conformity with needs can be ascertained because the developing party is the party who will use it as well. In accordance with the previous explanation regarding the type of innovation, SIMPUS can be categorized as process innovation that is process innovation related to ICT-based administration activities from registration until payment process. The novelty of SIMPUS innovation can be seen in the integration of data that occurs through sophisticated systems so that it can be accessed and utilized by the Health Department wherever and whenever. The ease of process and utilization becomes an important factor in the implementation of SIMPUS innovation throughout the health center.

2) The communication channel, where Rogers explains that a communication channel is a tool for delivering innovation messages from the source to the recipient. The process of diffusion of SIMPUS innovation involves many parties, including the Health Department and all health centers in Yogyakarta, so there are several strategies of communication approach used. The communication approaches used are (1) word of mouth used by the Surveillance and SIK Section in disseminating information regarding the existence of SIMPUS innovation in its development stage and (2) formal communication approach through centralized socialization which is followed by a representation of each health center. In addition, a formal approach is also done to provide assistance to each health center in Yogyakarta.

3) The time, in which Rogers explains downtime, is the innovation-decision process from starting someone to know until deciding to accept or reject it. Time elements are closely related to when an innovation is accepted and implemented by the target group where type decisions are taken in the process of diffusion of SIMPUS innovation when referring to Wayne's opinion explaining the types of innovation decisions that are (1) optional decision types, (2) types of collective decisions, and (3) types of authoritarian decisions [17]. Hence, it can be categorized into types of authoritarian decision and all health center must be willing to implement SIMPUS. Therefore, the process of diffusion of SIMPUS innovation has a span of time from 2011 to 2015. The decision of acceptance of each health center can be known in the process of socializing the SIMPUS innovation, but its application is done in stages. Stages in the process of diffusion of SIMPUS innovation can be seen in the chart below.

Fig. 2.

Time in Process Diffusion of SIMPUS

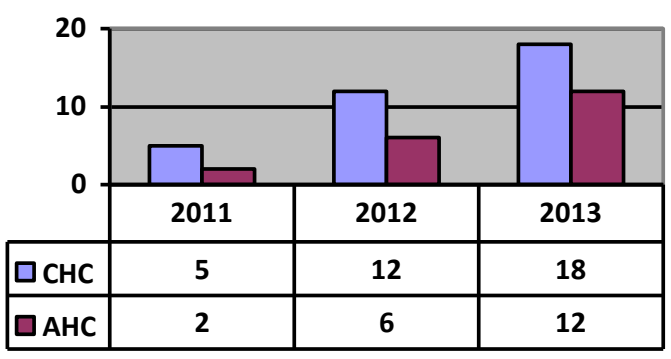

Source: Health Department of Yogyakarta, 2016

From the above data, it can be seen that the time span of the diffusion process of SIMPUS innovation in Yogyakarta City ranged from 2011 to 2013. From the first year, SIMPUS innovation can be applied to 5 central health centers and 2 auxiliary health centers, and then in the second year in 2012 SIMPUS innovation can be applied to 7 central health centers and 4 auxiliary health centers. While in the third year of 2013, SIMPUS innovation can be applied in all health centers in the city of Yogyakarta including 18 central health centers and 12 auxiliary health centers. The implementation of SIMPUS innovation is done gradually because of the different readiness of resources owned by each health center.

4) The social system relating to who the actors are involved in the diffusion process of innovation. There are at least two actors in the innovation diffusion process: innovators and target groups. In the process of innovation diffusion SIMPUS, the innovator is the Surveillance and SIK Section, while the target group is all health centers consisting of 18 central health centers and 12 auxiliary health centers. Rogers categorizes adopters based on their innovations: (1) innovators, (2) early adopters, (3) early majority, (4) late majority, and (5) laggards [19] [20]. When referring to the explanation, the adopter categories in the process of diffusion of SIMPUS innovation can be seen in the table below.

TABLE IV

Types of Adopters in Process Diffusion in SIMPUS

\begin{tabular}{|l|l|}
\hline \multicolumn{1}{|c|}{ Category } & \multicolumn{1}{c|}{ Party } \\
\hline Innovators & Section Surveillance and SIK \\
\hline early adopters & 5 central health centers and 2 health center auxiliaries \\
\hline early majority & 7 central health centers and 4 health center auxiliaries \\
\hline late majority & 6 central health centers and 6auxiliary health centers \\
\hline Laggards & - \\
\hline \multicolumn{2}{|c|}{ Source: Surveillance and SIK Section, 2016 }
\end{tabular}


The diffusion process of innovation is closely related to the adoption of innovations described by Rogers that is the mental process of an innovation to the decision, to adopt, or to reject and to confirmation of this decision [16]. From this definition, it can be understood that the process of diffusion of innovation is a mental process whereby a person or individual passes from the first knowledge of an innovation by forming an attitude toward innovation to decide, to reject, or accept to implement the innovation. Rogers explains the stages in the process of diffusion of innovation, among others (1) awareness, (2) interest, (3) evaluation, (4) trial, and (5) adoption [16]. Meanwhile, according to Ray, the process of diffusion of innovation is (1) knowledge stage, (2) stage of persuasion, (3) decision stage, (4) implementation stage, and (5) confirmation stage [18]. The field data show that there is a long stage in the process of diffusion of SIMPUS innovation in Yogyakarta City. Therefore, the implementation of SIMPUS innovation is done gradually. The stages in the process of diffusion of SIMPUS innovation are as follows:

1) Preparatory phase. In this phase, the Surveillance and SIK Section of Health Department of Yogyakarta City performs informal ascension to disseminate information related to the existence of SIMPUS innovation to every health center. Through the communication approach of sexually sensitive sectional, the Surveillance and SIK Section successfully disseminated SIMPUS innovation information to all health centers and other related parties. The approach used indicates one of the good strategies because each health center can get information directly from the innovator related to SIMPUS innovation. The approach used is effective enough to influence every health center in responding to the acceptance of SIMPUS innovation that is being developed. This is a gap that is seen as an opportunity because of the connection of each health center is connected. The dissemination of SIMPUS innovation information can spread quickly throughout the health centers even though SIMPUS is in the development stage.

2) Socialization stage. At this stage, SIMPUS innovation has been completed by the Surveillance and SIK Section. There is an approach strategy that is the centralized socialization followed by a representation of each health center. Centralized socialization aims to introduce and provide in-depth information to every health center that becomes the target group. This strategy was successfully implemented to disseminate in-depth information regarding the innovations of SIMPUS that have been made. The centralized socialization was conducted three times in stages. From the socialization activities conducted, a good response can be seen from every health center in Yogyakarta City.

3) Implementation and mentoring stage. This stage is a response from the previous stage. All health centers responded favorably to the acceptance of SIMPUS innovation. This can be seen from the seriousness and willingness to accept SIMPUS innovation although in its implementation it occurs in several stages. This is because the readiness of each health center is different. Not all health centers have resources that can be utilized to implement
SIMPUS innovation optimally. Therefore, the strategy used is through independent assistance at each health center. Assistance is done independently at each health center to do the mapping of the readiness of each health center, so it obvious whether the health center is ready or not. Health centers that are ready will be accompanied by the implementation of SIMPUS innovation, while health centers that are not ready yet will be assisted in preparing the implementation of SIMPUS innovation. At this stage, every health center will get periodic assistance for every officer responsible for SIMPUS operation at every health center.

The results of the field show that the process of diffusion of SIMPUS innovation in Yogyakarta City occurred gradually where the diffusion process of SIMPUS innovation can be successful, with the timeframe of 2011 to 2015 all health centers consisting of 18 central health centers and 12 auxiliary health centers can implement SIMPUS innovation. When referring to Rogers and Ray's opinion regarding the stages in the process of innovation diffusion, the stages in the diffusion process of SIMPUS innovation are not much different. This can be seen in the table below.

TABLE V.

Stages of Process Diffusion of SIMPUS

\begin{tabular}{|l|l|l|}
\hline $\begin{array}{l}\text { Process Stage } \\
\text { Diffusion Innovation } \\
\text { SIMPUS }\end{array}$ & $\begin{array}{l}\text { Stages Process } \\
\text { Diffusion } \\
\text { Innovation Rogers }\end{array}$ & $\begin{array}{l}\text { Stages Process } \\
\text { Diffusion } \\
\text { Innovation Ray }\end{array}$ \\
\hline Preparation & $\begin{array}{l}\text { Awareness } \\
\text { Interest }\end{array}$ & $\begin{array}{l}\text { Stage knowledge } \\
\text { Stage persuasion }\end{array}$ \\
\hline Socialization & $\begin{array}{l}\text { Evaluation } \\
\text { Trial }\end{array}$ & $\begin{array}{l}\text { Stage Persuasion } \\
\text { Stage decision } \\
\text { making }\end{array}$ \\
\hline $\begin{array}{l}\text { Adoption and } \\
\text { Implementation }\end{array}$ & Adoption & $\begin{array}{l}\text { Implementation } \\
\text { phase Stage } \\
\text { confirmation }\end{array}$ \\
\hline
\end{tabular}

Source: processed researchers, 2016

From the table above, it can be seen that the stages in the process of diffusion of innovation SIMPUS only has three stages. Although if referring to the opinion of Rogers and Ray associated with the process of the diffusion process of innovation SIMPUS, there is a more complex episode stage. This means that every stage in the process of diffusion of innovation SIMPUS has a more detailed series of activities and strategies. Therefore, the stages that occur at the stage of the diffusion process of innovation SIMPUS is not much different from the stage of diffusion process of innovation according to Rogers and Roy who describe each stage more detail.

\section{Factors Affecting the Successful Process of Innovation Diffusion of SIMPUS}

According to Rogers, there are four factors that influence the process of innovation diffusion that is (1) social structure, (2) norm, (3) opinion leaders, and (4) change agent [21]. In addition, according to Rogers, there are also five characteristics attached to innovation that affect whether sooner or later an innovation is adopted [16] [22]. These characteristics are a relative advantage, suitability, complexity, testability, and easy to observe. There are at least three important factors that influence the success of the diffusion process of SIMPUS innovation in Yogyakarta City where the three factors are one of the strategies of the 
Surveillance and SIK Section of Health Department of Yogyakarta City in the process of diffusion of SIMPUS innovation in all health centers. The three factors are as follows:

1) Clarity of the benefits of SIMPUS innovation where SIMPUS is developed in accordance with the need to integrate data throughout the public health centers in Yogyakarta City. Therefore, with the clarity of the benefits to be gained through the implementation of SIMPUS innovation, then all health centers respond well to accept. This shows that the right innovation is developed directly by those who will apply it. Hence, the appropriateness of innovation with the needs ascertained will be on target.

2) Appropriate communication strategy where the strategy of the approach used through getok tular affects the mutual influence both personally and institutionally from the whole health centers. This approach is useful for disseminating information related to SIMPUS innovation informally as innovation is developed. While after SIMPUS innovation successfully developed, the approach used changed into formal communication through centralized socialization activity. Therefore, all health centers provide good acceptance response, whereby all health centers can implement SIMPUS innovation. The approach is taken as a strategy for mapping the readiness of each health center as the target group. This readiness impacts on the implementation of SIMPUS innovation which is done in stages.

3) Assistance activities. This is the most important factor in the process of diffusion of SIMPUS innovation. It is because the assistance activities conducted independently at each health center by the Surveillance and SIK Section. Through this activity, every health center gets more attention related to the application of SIMPUS innovation. The mapping results provided an important input in the process of implementing the innovation of SIMPUS. The strategy is done by gradually implementing the innovation of SIMPUS. This is done because the readiness of each health center is different. Health centers that have resources than can directly apply and then continue with the assistance of the operation. While for health centers that are not ready yet will be given special assistance so that they can be really ready to apply SIMPUS innovation. Assistance is done independently by visiting each health center, so that the Surveillance and SIK Section really knows the real condition in every health center.

\section{THE CONCLUSIONS}

Conclusions of this research provide a framework for the process of diffusion of innovations in the public sector based on successful innovation cases. This proves that innovation is a long process that does not occur incidentally so that the results of this research are important to provide rational information to reduce the risk of failure for organizations, managers and innovators in the public sector to make the process of innovation diffusion.

This research found a framework based on empirical results, namely: (1) SIMPUS innovation type included in the category of innovation of technology-based administration process aimed at data integration at all health centers in
Yogyakarta City, (2) diffusion process of SIMPUS innovation following linear model simple wherein each stage starting from the preparatory stage, the socialization stage and the implementation-mentoring stage have their own activities and strategies running progressively, (3) the strategy used is formal through top-down approach, centralized socialization and mentoring and informal through a get-good-speech approach, and (4) the factors that affect success come from both internal and external factors that explicitly range from individual, group, organizational to environmental and cultural levels.

The conclusion of this research has the limitations to be a generalization of the diffusion process innovation framework in the public sector this is due to limited by one successful case study of innovation. It is also caused by the characteristics of public sector organizations (in this case the Health Department of Yogyakarta City) which from the beginning was designed to make changes to health services through SIMPUS innovation. This research provides practical recommendations to organizations, managers and innovators in the public sector to pay attention to every stage in the process of innovation diffusion. The important thing to note is whether organizations, managers and innovators in the public sector will create innovation or will adopt innovation because these two things are different. Reflecting on the results of this research shows that successful innovation is the result of the creation of the party who will apply it.

\section{ACKNOWLEDGMENT}

Acknowledgments the authors convey to all informants from the Health Department of Yogyakarta City and all health centers on data and information that has been given to the author.

\section{REFERENCES}

[1] F. Gault, "Defining and measuring innovation in all sectors of the economy," Res. Policy, vol. 47, no. 3, pp. 617-622, 2018.

[2] J. Hartley, E. Sørensen, and J. Torfing, "Collaborative Innovation: A Viable Alternative to Market Competition," Public Adm. Rev., vol. 73, no. 6, pp. 821-830, 2013.

[3] L. Carter-davies and S. Martin, "Improving Public Services : Existing Evidence and Evidence Needs Improving Public Services: Existing Evidence and Evidence Needs," Public Policy Institue for Wales, no. October, 2016.

[4] R. Safeena and A. Kammani, "E-Government Adoption: A Conceptual Demarcation,” Int. J. Manag. Inf. Technol., vol. 5, no. 1, 2013.

[5] P. Kumar, “An Analysis of Theories of Diffusion,” Am. Int. J. Res. Humanit. Art Soc. Sci., pp. 103-124, 2014.

[6] F. Kurniawan, N. A. Rakhmawati, A. N. Abadi, M. Zuhri, and W. T. Sugiyanto, "Indonesia local government information completeness on the web," Procedia Comput. Sci., vol. 124, pp. 21-28, 2017.

[7] G.-Z. Yang and Z. Yan, "A Contingent Technology Innovation Diffusion Model and Simulation,” Int. Conf. Manag. Sci. Manag. Innov., no. Msmi, pp. 310-315, 2015.

[8] M. Dibra, "Rogers Theory on Diffusion of Innovation-The Most Appropriate Theoretical Model in the Study of Factors Influencing the Integration of Sustainability in Tourism Businesses," Procedia Soc. Behav. Sci., vol. 195, pp. 1453-1462, 2015.

[9] D. Aizstrauta, E. Ginters, and M. A. P. Eroles, "Applying theory of diffusion of innovations to evaluate technology acceptance and sustainability," Procedia Comput. Sci., vol. 43, no. C, pp. 69-77, 2015 . 
[10] Y. Suwarno, Innovation in Public Sector. Jakarta : STIA LAN Press, 2008.

[11] X. Gao, J. Xu, G. Sorwar, and P. Croll, "Implementation of E-Health record systems and E-Medical record systems in China," Int. Technol. Manag. Rev., vol. 3, no. 2, pp. 127-139, 2013.

[12] J. Xu, X. Gao, G. Sorwar, and P. Croll, "Implementation of E-health Record Systems in Australia," Int. Technol. Manag. Rev., vol. 3, no. 2, pp. 92-104, 2013.

[13] M. M. H. Chowdhury, "e-Health in Bangladesh: Current Status Challenges, and Future Direction," Int. Technol. Manag. Rev., vol. 4, no. 2, pp. 87-96, 2014.

[14] J. W. Creswell, Qualitative Research and Research Design, 3rd ed. Yogyakarta: Pustaka Pelajar, 2015.

[15] Sugiyono, Administrative Research Methods. Bandung: Alfabeta, 2014.

[16] E. M. Rogers, Diffusion of Innovations, Fourth. New York: The Free Press : A division of Simon \& Schuster Inc., 2010.

[17] H. De Vries, V. Bekkers, and L. Tummers, "Innovation in the public sector: A systematic review and future research agenda.," Public Adm., vol. 94, no. 1, pp. 146-166, 2015.

[18] K. Lehmann, "Innovation diffusion theory," J. Gen. Manag. Res., vol. 3, no. 2, pp. 101-118, 2015.

[19] M. Q. Miranda, J. S. Farias, C. de Araújo Schwartz, and J. P. L. de Almeida, "Technology adoption in diffusion of innovations perspective: introduction of an ERP system in a non-profit organization,” RAI Rev. Adm. e Inovação, vol. 13, no. 1, pp. 48-57, 2016.

[20] M. Ali, "The Cultural Impact of Diffusion of IT Innovation in World Society,” Int. Conf. Recent Adv. Comput. Syst., no. Racs 2015, pp. 114-118, 2016.

[21] E. Fischer, "Socio-Technical Innovations in Urban Logistics: New Attempts for a Diffusion Strategy," Procedia Eng., vol. 178, pp. 534542, 2017.

[22] L. M. Aplin, "Understanding the multiple factors governing social learning and the diffusion of innovations," Curr. Opin. Behav. Sci., vol. 12, pp. 59-65, 2016. 